\title{
Establishment of mammary tissue culture: an in vitro model for bovine lactation*
}

\author{
H.H. Wu, X.J. Zhao, C.Q. Zhang and J.X. Liu ${ }^{1}$ \\ Zhejiang University, College of Animal Sciences, Hangzhou 310029, P.R.China
}

\begin{abstract}
A ruminant mammary tissue culture that accurately reproduces mammary function in vitro would be a valuable tool in studies of ruminant lactation. This study was conducted to establish an in vitro model for culture of lactating bovine mammary tissue. The tissue still maintained the activity at $72 \mathrm{~h}$, which was indicated by the value of MTT and oligonucleosomal fraction of cellular DNA. Under the conditions used in this study, the gene expression of $\alpha \mathrm{s} 1$ casein was highest at $8 \mathrm{~h}$, and then declined at 12 and $24 \mathrm{~h}$. The results suggest that this primary tissue culture system may be useful in studying the effects of different combinations of amino acids on milk protein in terms of as 1 casein in vitro.
\end{abstract}

KEY WORDS: mammary tissue, culture, bovine

\section{INTRODUCTION}

Accurate replication of in vitro bovine mammary gland function would be of great benefit to studies on the control of milk synthesis and secretion (Rose et al., 2002). There are a number of possible in vitro mammary incubation methods and some approaches have been developed to quickly and properly evaluate the redox activity and function of the cultured tissue.

Cell death in cultures will invariably take place by the process of apoptosis, in response to the low levels of environmental stress that cells are likely to experience in culture vessels (Cotter, 1995). Apoptosis is accompanied by the activation of endonucleases responsible for DNA fragmentation into oligonucleosomal fragments. Thus DNA laddering is considered to be an indicator of mammary epithelial cells apoptosis (Quarrie et al., 1996).

3-(4,5-Dimethylthiazol-2-yl)-2,5-diphenyltetrazolium bromide (MTT) reduction assay has been widely used for evaluating cell viability in culture. Zund et al. (1999)

\footnotetext{
* Supported by the Key Technologies R and D Programme of the $10^{\text {th }}$ Five-Year Plan from the Ministry of Science and Technology, P.R.China, No. 2002BA518A02-02

${ }^{1}$ Corresponding author: e-mail: liujx@zju.edu.cn
} 
employed the modified MTT assay to quantitatively assess the viable cell numbers of human aortic myofibroblasts grown on PGA scaffolds.

In the current study, we assessed the maintenance of mammary tissue redox activity and function in vitro using the MTT assay. The abundance of $\alpha_{s 1}$ casein mRNA in primary cultures of mammary tissue was then investigated to reflect the protein synthesis by the mammary cells. The reverse transcriptase (RT)-PCR was used to amplify the mRNA of $\alpha_{\mathrm{s} 1}$ casein in the system.

\section{MATERIAL AND METHODS}

\section{Reagents}

DMEM/F12 was obtained from Gibco BRL Life Technologies (Carlsbad, CA), reagents for DNA extraction were obtained from Sangon (Shanghai), reagents for RTPCR assay were purchased from Promega (Madison, WI). All other reagents were of the highest purity commercially available, purchased from Sangon (Shanghai).

\section{Source of tissue and treatment}

Mammary tissue was obtained at slaughter from two Holstein dairy cows in the middle stage of lactation. About $1 \mathrm{~g}$ of mammary tissue from each cow, cut into pieces of about $50 \mathrm{mg}$, was placed in every cryovial with dimethylsulphoxide (DMSO). The cryovials were stored in liquid nitrogen. Tissues in one cryovial were thawed and chopped to obtain pieces of about $1 \mathrm{~mm}^{3}$ before culture. About $1 \mathrm{ml}$ of tissues was plated into each tube for experiments involving RNA isolation. Explants were immediately incubated at $37^{\circ} \mathrm{C}\left(95 \%\right.$ air, $\left.5 \% \mathrm{CO}_{2}\right)$ by roller tube culture in medium DMEM/F12 (3 ml volume) containing 10\% FCS, $2 \mu \mathrm{g} / \mathrm{ml}$ hydrocortisone, $10 \mu \mathrm{g} / \mathrm{ml}$ insulin, $5 \mu \mathrm{g} / \mathrm{ml}$ transferrin and $5 \mu \mathrm{g} / \mathrm{ml}$ prolactin.

\section{MTT colorimetri assay}

The rate of replication of each tube was determined using MTT dye. The culture tissue was incubated for 24, 48, 72, 96 and 120 h, respectively. Partial tissue was then removed from each tube into a 24-well microculture plate. Four hundred $\mu 1$ of MTT dye $\left(1 \mathrm{mg} / \mathrm{ml}\right.$ in PBS, Sigma) was added to all the wells and the plate was incubated at $37^{\circ} \mathrm{C}$ in a $\mathrm{CO}_{2}$ incubator. After $4 \mathrm{~h}, 200 \mu \mathrm{l}$ of DMSO was added to all the wells to dissolve the formazan crystals, and the optical density (OD) was then measured at $570 \mathrm{~nm}$.

\section{DNA analysis}

Oligonucleosomal fraction of cellular DNA was extracted from mammary explants after 24, 48, 72, 96 and $120 \mathrm{~h}$ of culture, respectively, using kit SK1252 from Sangon. After electrophoresis on 2\% agarose gel, the DNA was stained with ethidium bromide and its oligonucleosomal fragments smaller than $1000 \mathrm{bp}$ for each stage were quantified by densitometry and expressed in arbitrary units. 


\section{RT-PCR assay}

Total RNA of mammary tissue was isolated using Trizol (InVitrogen). RNA integrity was verified by optical density $\mathrm{OD}_{260 \mathrm{~mm}} / \mathrm{OD}_{280 \mathrm{~nm}}$ absorption ratio $>1.65$. Oligonucleotide primers used in the RT-PCR assay were derived from the sequence of cow glyceraldehyde-3-phosphate dehydrogenase (GAPDH) mRNA (accession AJ000039, EMBL DNA sequences) and cow $\alpha_{\mathrm{s} 1}$ casein mRNA (accession M38641, EMBL DNA sequences). Primers for GAPDH were: 5'-ACG GCA AGT TCAACG GCA TCA-3' (sense) and 5'-CAG AGC CAA TGG GAT TAG GGA -3' (antisense). Primers for casein $\alpha_{\text {s1 }}$ were: 5'-TGG GAG TGA ATC AAC TGA GGA-3' (sense) and 5'-CAG AGC CAA TGG GAT TAG GGA-3' (antisense). Synthesis of first strand of DNA was performed with reverse transcriptase (MMLV-RT, Promega, Madison, WI) and each specific primer according to the manufacturers instructions.

\section{Statistical analyses}

Statistical analyses were undertaken using the GLM procedure of SAS.

\section{RESULTS AND DISCUSSION}

There was no significant difference in the optical density of MTT among the different times of culture up to $120 \mathrm{~h}$, which suggests that under the condition used, the tissues redox activity may be maintained for several days. Mean values of optical density of gel lines obtained from 3 replicates, and representative gel photographed under UV illumination are presented in Figure 1. Distinct ladder-like patterns of DNA fragmentation, characteristic of apoptosis, were evident after $24 \mathrm{~h}$ of culture. The lowest value was observed after $48 \mathrm{~h}$ of culture.

Amplification by RT-PCR confirmed the presence of $\alpha_{s 1}$ casein mRNA in the lactating mammary tissue. As expected, a 434bp DNA fragment was amplified, the derived RT-PCR products were sequenced and 100\% homology to the published sequences was given. The $\alpha_{\mathrm{s} 1}$ casein expression on bovine mammary gland explants is shown in Figure 2. The highest value of $\alpha_{s 1}$ casein expression was observed in mammary tissue cultured for $8 \mathrm{~h}$, which means the highest level of mammary protein synthesis responded to prolactin. This result suggests that the mammary tissues cultured in vitro maintain their secretory activity.

\section{CONCLUSIONS}

Under the conditions used in this study, the roller tube methods could maintain the basic active state of the cultured tissue. And the tissues initially synthesize large amounts of the components of milk, such as $\alpha_{\mathrm{s} 1}$ casein, in respects to prolactin. The model may be used to study the effects of different combinations of amino acids on milk protein in terms of $\alpha_{\mathrm{s} 1}$ casein in vitro. 
A

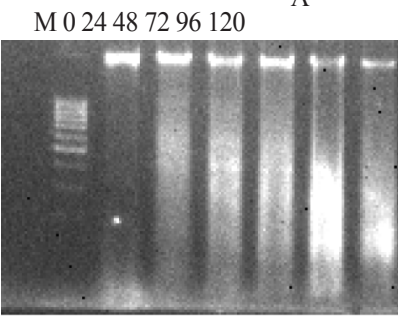

B

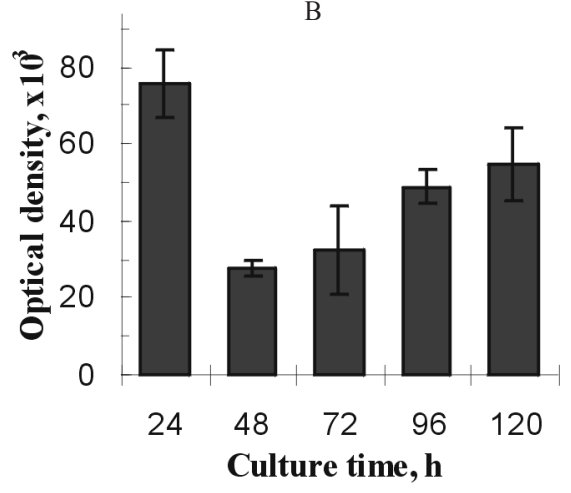

Figure 1. Low molecular weight DNA extracted from cultured bovine mammary explants (M - standard weight marker). A. Agarose gel electrophoresis. B. Means of optical density of the electrophoretic DNA fragment lower than $1000 \mathrm{bp}$ (10 replicates for each timepoint)
A
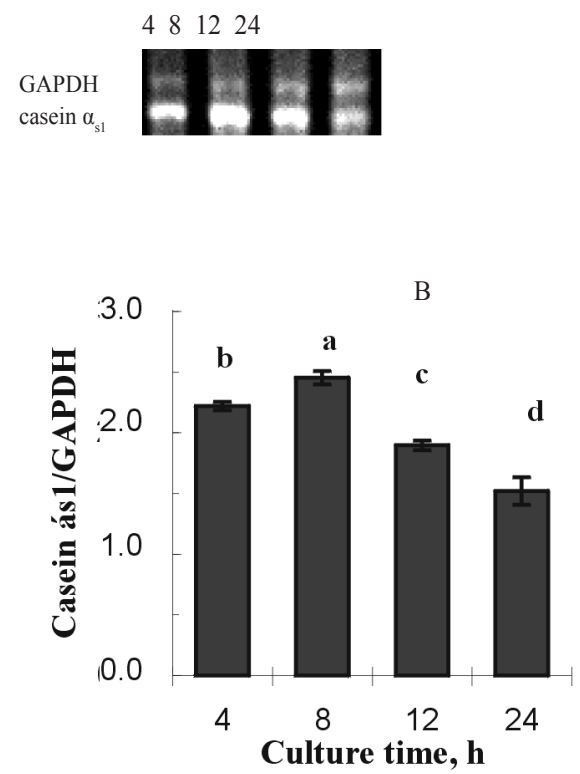

Figure 2. RT-PCR of GAPDH and $\alpha_{\mathrm{s} 1}$ casein mRNA from bovine mammary gland explants with $5 \mu \mathrm{g} / \mathrm{ml}$ prolactin. A. Agarose gel electrophoresis. B. Means of optical density of electrophoretic bands expressed in the ratio of arbitrary units of $\alpha_{s 1}$ casein and GAPDH. Means with different letters are significantly different $(\mathrm{P}<0.05)$

\section{REFERENCES}

Cotter T.G., Al-Rubeai M., 1995. Cell death (apoptosis) in cell culture systems. Trends Biotech. 13, $150-155$

Quarrie H.L., Addey C.V.P., Wilde C.J., 1996. Programmed cell death during mammary tissue involution induced by weaning, litter removal, and milk stasis. J. Cell. Physiol. 168, 559-569

Rose M.T., Aso H., Yonekura S., Komatsu T., Hagino A., Ozutsumi K., Obara Y., 2002. In vitro differentiation of a cloned bovine mammary epithelial cell. J. Dairy Res. 69, 345-355

Wheeler T.T., Callaghan M.R., Davis S.R., Prosser C.G., Wilkins R.J., 1995. Milk protein synthesis, gene expression, and hormonal responsiveness in primary cultures of mammary cells from lactating sheep. Exp. Cell Res. 217, 346-354

Zund G., Ye Q., Hoerstrup S.P., Schoeberlein A., Schimid A.C., Grunenfelder J., Vogt P., Turina M., 1999. Tissue engineering in cardiovascular surgery: MTT, a rapid and reliable quantitative method to assess the optimal human cell seeding on polymeric meshes. Eur. J. Cardiothorac. Surg. 15, 519-524 